\title{
Poetics of the Eschatological Plot in the Novels by G. Gazdanov
}

\author{
Elena N. Proskurina* \\ Institute of Philology of SB RAS \\ 8 Nikolaev Str., Novosibirsk, 630090, Russia
}

Received 04.03.2015, received in revised form 11.04.2015, accepted 10.05.2015

\begin{abstract}
The article analyzes eschatological poetics by G. Gazdanov. The author's dramatic emotional experience of the catastrophical essence of human history and being is based on the conviction that the history of the mankind started "on the day when Cain slew his brother" ("The Spectre of Alexander Wolf"), i.e. at that very moment when man perceived in his own nature "the appeal of murder". The novels by Gazdanov are abundant with various kinds of deaths, both real and potential, merging into a single hyper plot of life under the sign of death. Among the manifestations of eschatological poetics in the whole Gazdanov's metanovel prose there are the motives of Apocalypse appearing in the characters' visual images, aural associations, physical sensations. Meanwhile, Gazdanov ranks peculiarly in the historical and literary context of the young emigration. The author's artistic strategy is marked by an optimistic stoicism uncharacteristic for the self-consciousness of the generation. His entire literary path represents the overcoming of tragic sensation of being. Herewith, a peculiar role belongs to the character, who more often becomes the winner in the combat not so much with real mortal circumstances as with overpowering mental apathy threatening him with spiritual death.
\end{abstract}

Keywords: novels by G. Gazdanov, plot poetics, literary motif, eschatology.

DOI: 10.17516/1997-1370-2015-8-7-1486-1493

Research area: philology.

The literary path of G. Gazdanov, one of the brightest representatives of Russian young emigration, embodies the creative overcoming of the tragic feeling of being dissolved in his poetic world and based on the conviction that the history of the mankind started "on the day when Cain slew his brother", i.e. at that very moment when man perceived in his own nature "the appeal of murder”. (Gazdanov, 1996, II, 102). This existential position seems more hopeless than the position of his contemporary B. Poplawski, which researchers take as an ideological maximum of the young emigrants generation (Semenova 2003, 312). In his article "On the Mystical Atmosphere of Young Literature in Emigration" Poplawski wrote, "Christ has been on the verge of death from the beginning to the end of the world. Therefore, the atmosphere of agony is the only decent atmosphere on Earth ... How shall we live? - Die ... Emigration is a perfect setting for this" (Poplawski 1930, 309). This statement reinterprets Pascal's idea given in the book by

(C) Siberian Federal University. All rights reserved

* Corresponding author E-mail address: proskurina_elena@mail.ru 
L. Shestov "On the Scales of Job": "Jésus sera en agonie jusqu'à la fin du monde: il ne faut pas dormer pendant ce temps-là" (Shestov, 1993, p. 281 ) ("Jesus will be in agony until the end of the world: one should not sleep during this time" (fr.) (Ibid, 543)). Not taking into consideration the philosopher's reference to Gethsemane night, urging Christ to wake ("And He took with Him Peter and the two sons of Zebedee, and began to be grieved and distressed. Then He said to them, "My soul is deeply grieved, to the point of death; remain here and keep watch with Me" (Matthew, 23: 37-38)), Poplawski creates a formula of the complete existential despair. It seems that the conclusion of Gazdanov given above is even more desperate, while it concerns not only the state of mind of the human, but the original distortion of their very nature. However, the writer himself and his characters move closer towards spiritual waking, as if responding to the call of the Savior, and the French philosopher who echoes him. Shestov's metaphysical system allows this not for all, "but only for some, "rare chosen ones" - or "martyrs". For if they fall asleep, the victim of God would be in vain and death will prevail in the world once and for all" (Shestov 1993, 324). Perhaps it is due to Gazdanov's opposing to the existential dead end that I. Babel in his interview with Iu. Annensky in early 1930's called him "heroic Gaito Gazdanov" (Gazdanov 1994, 248).

Let us turn to a more detailed analysis of the eschatological story of the writer. Gazdanov's prose is abundant with various kinds of deaths, both real and potential, merging into a single hyper plot of life under the sign of death. This paper focuses on the series of novels consisting of two subcycles: the "Russian" novels with the prevailing theme of the fate of Russian immigrants in France, which include six novels written in the 1930's - 40's: "An Evening with Claire", "The History of a Journey", "The Flight", "Night Roads", "The Spectre of Alexander Wolf', "The
Buddha's Return"; and "French" novels written in 1950's - 60's: "Pilgrims", "The Awakening". The final novel, "Evelyn and Her Friends" plays a synthesizing role. It is a kind of a punch line putting the semantic emphasis pronounced in previous works ${ }^{1}$.

The semantic function of the entire metanovel plot by Gadznov at the eschatological level is the Bible motif of the fratricide, which appears in the speech of one of the heroes of "The Spectre of Alexander Wolf", echoing in a variety of forms in each of his works. Thus, one of the benchmarks of the ontologically damaged humankind, which lost its original immortality, is high frequency of the motif of an illness leading to death in all the novels. In "An Evening with Claire" it is the illness and death of the father, death of the protagonist's sisters, etc.; in "The History of a Journey" it is the illness and death of Alexander Alexandrovich; in "Night Roads" it is the illness and death of Raldi, consumption of Alice as a sign of soon death, etc. The genetic imprint left by the Biblical drama from the point of view of Gazdanov, is manifested in the very ability of the human to kill as a return to the ancient instinct, which had obtained the status of the "heredity law", blood revenge (which was up-to-date for the family memory of the writer-Ossetian).

In our opinion, the author's idea of the damage to human nature implied by Cain's sin represents the source of the criminal theme, which occupies a significant place in the novels making them similar to fictional prose and organizing the appropriate narrative kernel of criminal deaths, perhaps, the largest in all the diversity of Gazdanov's death plots. They include the murders out of greed ("Night Roads"), and the murders in a drunken brawl ("The History of a Journey"), and the murder out of jealousy ("The Spectre of Alexander Wolf") and many others. At the level of the character's poetics, the ability to murder is a part of a "spiritual biography" of the hero, 
including autobiographical. Thus, the narrator of "Night Road" admits that the hypothetical ability of murdering is one of the components of his inner world; Arthur, the hero of "The History of a Journey", has similar feelings. Let us note once again that these are not only negative characters, but also the characters close to the author, which serves as a way for Gazdanov's artistic selfanalysis, deep and often painful self-reflection.

The Biblical drama has made tragic damage to the natural world, where the spirit of rivalry and death has also appeared. The most striking examples are the deadly battle of ants with a tarantula, a dying owl and a dying eagle in "An Evening with Claire", the death of goldfish jumping out of an aquarium with superheated water unnoticed by the characters in "The Spectre of Alexander Wolf" and others. This is the way the author builds the motif of ethical responsibility of the human for existence, for "every living thing" that "has been groaning right up to the present time" into his metaplot (Rom. 8: 22).

One eschatological manifestation of Gazdanov's poetics is "stitchedness" of the entire metanovel with apocalypse motifs appearing in visual images of the heroes, sound associations and bodily sensations. The novel "An Evening with Claire" is filled with the apocalyptic mood as a presentiment of a universal catastrophe represented by the image of earth on fire, the motif of darkness associated with falling into the abyss. The narrator has the same associations in case with a shrilly sound. Similar motif appears on the pages of "The History of a Journey".

It is symptomatic that the author vividly delineates the universal, Russian and European apocalypses. When the autobiographical hero sees the pictures of the Russian apocalypse in "An Evening with Claire", national motifs arise: the sound of the harmonica and the street-organ, the winter cold of streets. Images of the sinking ship and red flame in the novel are also loaded with the symbolism of Russian revolutionary events: as a symbol of forever lost homeland burnt in the fire of revolution and civil war. The European apocalypse is symbolized by means of the image of Paris as a dead ghost-city washed by the dark waters of the Seine, with a maze of dark, stinking streets, the ruins of collapsed buildings, squalid dens where "human carrion" is reigning. The dark side of the Parisian capital is most vividly shown in "Night Roads" and "The Buddha's Return". Moreover, the characteristic of Paris as "a sinister and fantastic city" in "Night Roads" refers to the Russian classical tradition of Saint Petersburg's image: to the artistic worlds of "The Queen of Spades", "The Bronze Horseman" by Pushkin, "Petersburg Stories" by Gogol, Saint Petersburg of Dostoyevsky and others. This poetic method of identification of the two capitals may speak for the author's and his hero's perception of Paris as a French Petersburg. However, such paralleling is contrary to the fact that the image of St. Petersburg in Gazdanov's works has a light connotation - as the city of his childhood, adolescence, first love of his autobiographical hero. Despite the fact that it is St. Petersburg, where the young hero of the novel "An Evening with Claire" first experiences the fear of nothingness (we return to this observation later), it does not put any tragic imprint of "the kingdom of death" on the city.

Such a figurative delineation of two worlds: the Russian and the European - marks them as friend or foe. Although the writer himself and his autobiographical hero left Russia in early adolescence, for them it continues to be their space, a place of spiritual attraction, while Europe, where the main part of their lives takes place remains an alien world with the fate of outcasts awaiting for them. It is no accident that in Gazdanov's “Russian” novels special attention to the life of Parisian "bottom" as one of the loci of death marked the high frequency of the motifs of 
suicide and disappearance, which are motivated by despair, meaninglessness of existence, absence of the social status, the loss of the homeland, etc.

The emigrant position of Gazdanov's hero as an alien among aliens is due to the central position of the liminal (borderline) phase of trial with death in the metaplot of his "Russian" novels. It includes visionary dreams, visions of the hero, in which he seems to go beyond the reality plunging into the world of his dreams and visions that becomes the evidence of his borderline existence between life and death. The visions of the hero draw the history of humanity manifested in the change of cultures, eras, human generations in the space of his real and virtual memories. Oneiric paintings passed through the consciousness of the hero in all the richness of unpredictable multi-level relationships contribute to the formation of a lyrical tone of Gazdanov's narration. The dominance of the motifs of leaving and irrevocability gives an elegiac tone to the fragments of the plot putting an imprint on all novels.

The memory of the homeland fading with time, its tarnishing image in the minds of the Russian heroes give a special dramatic effect to the emigrant theme of Gazdanov's novels increasing in the creative process. At the same time, it only indirectly touches the traditions of the Russian classical literature connected with the theme of destruction/depopulation of family nests, and is dominant in the prose of the "senior" emigrants, for example, in the works of Bunin (Kapinos, 2012). In the body of "Russian" novels the motif of the ruined home, death of the family is most distinct only in the Gazdanov's first novel "An Evening with Claire", is shown as a dotted line in the "The History of a Journey" and only sketchily outlined in one of the episodes of "The Flight". Basically, the entire subcycle is united by the existential idea of movement of the human history into the unknown, the death of civilizations, cultures, cities, personified by numerous deaths of historic figures, artists, at the end of which, however, the picture of the Last Judgment can be observed.

Motifs of the destruction of home and family in the first novel of the "French" novels, "Pilgrims", are associated with the story line, which goes back to the genre of the social problem novel, when the hero is an unloved descendant of a poor family ruining themselves in drunkenness, debauchery and criminal collisions. Remaining one-on-one with the cruel world, he builds a relationship with it following the pattern taken from his own childhood experiences. This is the way Fred is, this is the beginning of the independent life of Janine. In the second "French" novel, "The Awakening", the death of relatives sharpens the sense of loneliness and confusion about the future, activates the intentions to create his own world in the hero of the novel, "an average Frenchman" Pierre Forey. In both cases, the situation with the death of the family becomes the starting point for building a parable story of the spiritual deathresurrection of the hero.

In the "Russian" novels, the apocalyptic worldview initiates the fear of death in the soul of the autobiographical hero, often struggling with the countless attraction of death. A special place in this series takes the story line of the father's death in "An Evening with Claire", which opens the "death gene" in the young hero Kolya Sosedov and becomes the starting point in the formation of the metanovel keynote of the fear of death. The motif of attraction of death appears for the first time in "An Evening with Claire" - in the window scene, when little Kolya Sosedov charmed by the sound of the saw coming from behind the window and fascinatingly watching sawyers' work in the yard, hangs more and more out of the window and almost falls out of it, already feeling the cold air - the breathing of death. This scene becomes a premonition of the hero's visionary 
journeys. Associations with death increase the mortal semantics of the motif of crossing the sea in search for other shores in the final episode of the novel, symbolizing the entry of the hero into the space of otherness. Hereafter, this motif will repeatedly vary in other novels.

Gazdanov's narrative space is marked by numerous random, unmotivated deaths. In addition to the above cases, it is the death of an official in "An Evening with Claire", who was awkwardly discharging the hunting rifle and released "the full charge of the birdshot into his forehead" (Gazdanov, 1996, I, 58), an accidental death of a passenger on the crashed airliner in "The Flight" and others. Such absurd situations appearing in Gazdanov's novels open the original existential feeling of the mystery of existence and human destiny, artistic representation of the maxim "death is everywhere". However, in some cases, deaths of this kind provide a semantic overtone of the deserved recompense for the unjust life, i.e. give parable modality to the existential story. In "The Buddha's Return" it is the elder brother of Shcherbakov, who drowned while swimming in the sea, who earlier refused from their fraternal relations; in "Pilgrims" it is the former pimp and murderer Fred fallen into the abyss at night; in "Evelyn and Her Friends" it is a miser George, who as senior Shcherbakov in "The Buddha's Return" abandoned his brother, etc.

Love of the characters in all Gazdanov's novels is also part of the plot of life under the sign of death. Especially vividly this maxim is realized in the images of Gazdanov's heroines, often depicted in the colours of death, despite the apparent lightheartedness and courtesy. Repeated episodes in the cabaret, restaurant or cafe in Gazdanov's novels contain the scene with a central image of a heroine sitting at a table or a bar (Raldi in "Night Roads", Valentine in "Pilgrims", Evelyn in "Evelyn and Her Friends", etc.) associated with the Impressionist paintings ("The Absinthe Drinker" by Pablo Picasso, "Bar at the Folies-Bergere" by Manet, "Woman in Tavern" by L.Valtat, etc.), becoming a part of the context of "gloomy poetry of the human fall" (Gazdanov 1996, I, 478), its peculiar vivid comment giving it an additional semantic scope expressed in a form, colour, as well as a special, "apocalyptic" tone of the central female figures. The writer used the art deco style as a model for his poetics and the red and black colours, which appear mainly in his heroines' images (black stockings, a black dress and always bright red lips) correlate with the poetics of the cabaret. The funeral semantic shade of such colour combinations is enhanced by the set of motifs containing the idea of the tragedy of being. These are the motifs of sadness, bitterness, physical pain and sensory exhaustion that accompany the theme of love and often predict its tragic ending. Thus, after the first, long-awaited night of love of Nikolai Sosedov and Claire in the novel "An Evening with Claire", the hero experiences a sudden rush of sadness associated not only with the idea of achieved happiness as the beginning of "the death of love": this sadness seems to be radiated by the body of serene sleeping Claire. In all subsequent novels some internal breakdown will be definitely felt in the intensity of the sensory world of the heroine (Victoria in "The History of a Journey", Lisa in "The Flight", Elena in "The Spectre of Alexander Wolf", Lida in "The Buddha's Return", Sabina in "Evelyn and Her Friends"). The pain of love in the episodes can be shown in different ways: either bodily or internal pain, something as a burn, etc. Thus, the traditional archemodel of the unity of Eros and Thanatos in Gazdanov's novels acquires a particular semantic content identifying the "fatal" kernel of the love story which was initiated in the writer's early story "The Black Drop" (supposedly at the beginning of the 1930's. $(\text { Krasavchenko, 2000, 239)) })^{2}$. 
The sense of the tragedy of being is peculiarly connected with viability of Gazdanov's hero, who in the novels of the writer is the figure of the unmatched value: in rather frequent situations of the combat with the death, he always remains alive getting each time a new experience of resisting life's hardship. In "An Evening with Claire" the school of maturing for Nikolai Sosedov was his participation in the Civil War, in "The Flight" it was the love drama experienced by young Sergei, in "The Spectre of Alexander Wolf" it was the fight of the nameless hero with the antiherotwin, in "The Buddha's Return" it was hero's overcoming of his strange illness manifested in the duality of consciousness, in "Pilgrims" it was the fight of Robert and Fred and Fred with himself at the same time, etc. The story line of the combat marking every Gazdanov's novel, according to the laws of the genre "requires sacrifice", which are "twins" or opponents of the hero, and in some cases - the heroine, which is always in the subordinated position to the hero.

With the increasing moralizing tendencies in the novels by Gazdanov, the trophy of the death are the characters that take the antihero function in the plot, such as Dr. Shtuck in "The History of a Journey", the characters gathered together on the plane in "The Flight", the blackmailer Charpentier in "Pilgrims", the gangster Canelli in "Evelyn and Her Friends", etc. As a result, an apocalyptic metanovel plot is formed similar to the Biblical one, when the author builds the fate of his characters, "pardons" and "punishes" them in full accordance with the law of God's judgment: the characters who stopped in their spiritual development, die or lose the perspective in the plot, while the heroes focusing on spiritual growth are given the opportunity to carry it out. Thus, in the narrative world of Gazdanov the punishment catches those up, who committed a moral crime against themselves. Those who have not lost their internal reserves and are ready to overcome the cruel fate are given the opportunity of new life journeys.

One of the main ways to overcome the fear of death in Gazdanov's novels is the author's irony manifested most often in the accompanying storylines. Thus, depicting the love drama of the heroes of "The Flight", the writer slightly mentions the novel by Fyodor Sletov and the owner of funeral houses varying the same situation in "The Buddha's Return" - an episode of the wedding of the concierge's daughter's and the employee of the funeral house, which brings some ironic modality to the narrative archetype of the unity of Eros and Thanatos. Moreover, these episodes demonstrate the ironic transformation of the archaic perception of death by the "collective unconscious", which F. Ares calls "tamed death" (Aries, 1992) - the attitude to death as a common phenomenon, which does not inspire fear. In Gazdanov's novels, however, such "pragmatism" of characters hides a secret fear of death, which emerges, for example, in the episode of the funeral of Pierre in "The Flight", when participants come to solve their everyday problems, as if proving their own "imaginary immortality" to themselves. The author's irony is even more distinct in the situation varying the classic love scene near the dead. In "The Flight" it is the scene of "uncontrollable desire" for Lola of the doctor, who came to witness the death of her lover, in "The Awakening" it is the satisfaction of lust of Justine and her lover near Justine's another lover, who has just died in her bed. Let us also name plenty of "literary" deaths made-up by Gazdanov's characters using the "yellow" samples. These are the deaths of their non-existent relatives and children, when they try to show with their sentimental reactions that they are better than they really are, to arouse pity and compassion for themselves, often guided by selfish considerations. There especially many of such imaginary stories in the novel "The Flight": 
Liudmila's made-up story about the death of her never existed daughter in order to get money from a fan as for the funeral of her child; her fictional scenes of her non-existent brothers dying from consumption, sisters broken by paralysis; the unexpected death of the hated spouse of Lola Ene, who in her imagination suddenly appears as the perfect lover arousing her sentimental feelings for him, etc.

Therefore, the eschatological plot in Gazdanov's novels share one main formula: life is the shadow of death. In the context of its main maxim: the history of the world began with the fratricide - this existence is justified while there are no innocent in the humanity, each of the descendants of Cain have the genetic print of the first biblical drama. Gazdanov identifies a common archetypal foundation of the literary plot structure of death, its projectiveness with respect to the Bible stories - in many variations, transformations and modifications. In the opinion of the writer, it is impossible to overcome the eschatological scenario of the general movement of the history, but one can save or educate themselves, improve their inner world, the key to which is the moral beginning in the man. The author proposes an example of such stoicism in the storylines of his protagonists, who reach the stage of spiritual growth by challenging combats with the destiny.

\footnotetext{
1 For more detail about the cycled unity of Gazdanov's novels, which structurally coincides with the large cyclic form in music, see: [Proskurina 2009].

2 For more details see: (Proskurina 2009, 68-72).
}

\section{References}

1. Aries, F. (1992) Chelovek pered litsom smerti [Human in the Face of Death]. Moscow: Progress - Progress-Akademiia. 528 p.

2. Gazdanov, G. (1994) Ia vsegda zhil v nishchete. Vremia i my [I Have Always Lived in Poverty. Time and Us]. Moscow-New York. No. 123, pp. 248-272.

3. Gazdanov, G. (1996) Sobranie sochinenii [Collection of Works]. In 3Volumes. Moscow: Soglasie.

4. Kapinos, E.V. (2012) Malye formy poezii i prozy (Bunin i drugie) [Small Forms of Poetry and Prose (Bunin and Others)]. Novosibirsk: Otrkyty kvadrat, pp. 138-167.

5. Krasavchenko, T.N. (2000) Gadzanov-ekzistentsialist: Dva rasskaza i fragment iz arkhiva v Garvarde. Vozvrashchenie Gaito Gazdanova. [Gazdanov-existentialist: Two Stories and a Fragment from the Archives in Harvard. The Return of Gaito Gazdanov]. Scientific Conference Devoted to the 95 $5^{\text {th }}$ Anniversary of His Birthday, December 4-5, 1998. Moscow: Russkii put', pp. 239-243.

6. Poplawski, B (1930) O misticheskoi atmosphere molodoi literatury v emigratsii. Chisla. [About the Mystical Atmosphere of Young Literature in Emigration. Figures] No. 2-3, pp. 308-311.

7. Proskurina, E.N. (2009) Edinstvo inoskazaniia: O narrativnoi poetike Romanov Gaito Gazdanova. [The Unity of Circumlocution: About the Narrative Poetics of Gaito Gazdanov's Novels] Moscow: Novy Khronograf. 391 p.

8. Semenova, S. (2003) Russkaia religiozno-filosofskaia mysl' i porevolutsionnye techeniia 1930-kh godov v emigratsii [Russian Religious and Philosophical Thought and Revolution-Caused Tendencies of 1930's in Emigration]. Gacheva A., Kaznina O., Semenova, S. Filosofskii kontekst russkoi literatury 1920-1930-kh godov [Philosophical Context of Russian Literature of 1920-1930's] Moscow: Institute of World Literature of RAS. Pp. 288-319. 
9. Shestov, L. (1993) Na vesakh Iova [On the Scale of Job]. Shestov, L. Essays" in 2 Vol. V. 2. Moscow: Nauka. V.2. 558 p.

\title{
Поэтика эсхатологического сюжета
}

в романной прозе Г. Газданова

\author{
Е.Н. Проскурина \\ Институт филологии СО РАН \\ Россия, 630090, Новосибирск, ул. Николаева, 8
}

\begin{abstract}
Статья посвящена анализу эсхатологической поэтики Г. Газданова. Авторскому сознанию писателя присуще напряженное переживание катастрофичности человеческой истории и бытия, основанное на убежденности в том, что история человечества началась «в тот день, когда Каин убил своего брата» («Призрак Александра Вольфа»), т.е. в тот момент, когда человек ощутил в своей собственной природе «притягательность убийства». Романная проза Газданова изобилует разного рода смертями, реальными и потенцииальнылии, объединяющимися в единый сверхсюжет жизнь под знаком смерти. Одним из проявлений эсхатологической поэтики Газданова является присутствие во всем метароманном тексте мотивов апокалипсиса, которые предстают в визуальных образах героев, звуковых ассоциациях, телесных ощущениях. При этом в историко-литературном контексте молодой эмиграции Газданову принадлежит особое место. Творческая стратегия писателя отмечена нехарактерным для поколенческого самосознания оптимистическим стоицизмом. Весь его литературный путь представляет собой преодоление чувства трагизма бытия. И здесь особая роль отведена герою, который чаще всего становится победителем в поединке не столько с реальными смертельными обстоятельствами, сколько с одолевающей его дущевной апатией, грозящей духовной смертью.
\end{abstract}

Ключевые слова: романы Г. Газданова, поэтика сюжета, литературный мотив, эсхатология.

Научная специильность: 10.00.00 - филологические науки. 